\title{
The sources for orthodox and heterodox trade and industrial policies in Brazil
}

\author{
A origem das politicas ortodoxas e heterodoxas \\ para o comércio e indústria no Brasil
}

JAN-ULRICH ROTHACHER*

RESUME: Ao longo dos últimos anos o governo brasileiro tem promulgado uma mistura de políticas ortodoxas e heterodoxas para o desenvolvimento econômico. Este trabalho visa testar se as ideias econômicas existentes têm sido prescritivas na formulação das políticas, ou se têm sido o resultado da "infusão de interesses privados" (Katzenstein, 1978) no processo de decisão política. Para esse efeito, o artigo traça as origens da abertura unilateral para o comércio no agronegócio e as contrasta com o processo político na indústria automobilística, onde as barreiras comerciais foram erguidas. $\mathrm{O}$ artigo irá identificar os canais através dos quais os atores privados informaram as intervenções do governo e mostrar que os organismos da indústria estimularam o governo. O labirinto político resultante deixou insatisfeitos tanto os representantes ortodoxos bem como aqueles da abordagem heterodoxa, e não conseguiu parar o encolhimento da capacidade manufatureira do Brasil.

PALAVRAS-CHAVE: abordagem social; política industrial; agronegócio; indústria automobilística; lobby; Brasil.

ABSTRACT: The Brazilian government has over the past years promulgated a mix of orthodox and heterodox policies for Brazil's economic development. This paper seeks to test whether the existing economic ideas have been prescriptive in formulating the policies, or whether they have been the outcome of the "infusion of private interests" (Katzenstein, 1978 ) in the policy making process. To this end, the paper charts the origins of the unilateral opening for trade in the agribusiness and contrasts them with the policy process in the car industry, where trade barriers have been erected. The article will identify the channels through which private actors informed the government's interventions and show that the industry bodies have largely prodded the government. The resulting policy maze has left both the representatives of the orthodox as well those of the heterodox approach unsatisfied and has failed to halt Brazil's dwindling manufacturing capabilities.

KEYWORDS: societal approach; industrial policy; agribusiness; car industry; lobbying; Brazil. JEL Classification: F13; L52; L62; L66.

\footnotetext{
* Faculty of Social Science, Ruhr-Universität Bochum, Germany. E-mail: Jan-Ulrich.Rothacher@ruhruni-bochum.de. Submitted: 22/May/2015; Approved: 16/July/2015.
} 


\section{INTRODUCTION}

Brazil's unilateral foreign economic policies have been marked by two contradictory trends of protectionist and neoliberal policies. Their stark contrast has been particularly pronounced over the past years. There is now a broad consensus that Brazil's stability oriented policies that dominated until Lula da Silva's second term - dubbed by its critics as orthodox or neoliberal - has been complemented with an increasing streak of state interventionism. According to observers, orthodox policies and the new state interventions nowadays co-exist "in parallel" (Morais and Saad-Filho, 2012, p. 790), while Ban (2013, p. 299) discerns a "hybrid" economic policy model, where both, goals grounded on neoliberal traditions and those derived from the heterodox strand, are being pursued, whereas Arbix and Martin $(2010$, p. 7) identified a new "state activism without statism".

In the field of foreign economic policies, the Brazilian government has most notably left the path of non-interference and unilateral tariff cuts with the introduction of the new automotive regime called Inovar-Auto. Within the car industry, the Brazilian government has in the past years enunciated a total of sixteen trade policy measures, out of which five discriminated against foreign commercial interests (Oh, 2014, p. 649). These measures are therefore hardly neoliberal. But at the same time, the Brazilian government has furthered its neoliberal credentials in selected sectors, such as in agriculture. Therein, the Brazilian government has attempted to open foreign markets through bilateral free trade agreements and by influencing the multilateral WTO-trade talks (Hopewell, 2014, p. 303). Moreover, the Brazilian government has abolished most custom duties on inputs used by the Brazilian farmers and eased the regulations for a market entry, which is akin to neoliberal policy prescriptions.

This has left proponents on both sides unsatisfied. While Luiz Carlos Bresser-Pereira, one of the most vocal champions for a more activist economic policy, awaits the rolling out of a national development strategy that would encompass all of Brazil's industries, the neoliberals are disheartened by the stalled overall opening of the Brazilian economy. The inchoate economic policies show that Brazil has neither been able to copy the economic recipes of Chile or Mexico, which according to the World Bank (2014, p. 30) embraced free trade, which subsequently spurred productivity, nor has it pursued a holistic industrial policy that would systematically upgrade and accompany a "deep productive transformation" of the Brazilian economy (Carrillo, 2014, p. 59).

This flurry of activities and their incoherence engenders the research question, how these contradictory industry-specific economic policies came about. To delineate the sources for these policies, this paper shall reconstruct the process of the policy formulation for two different industries, the car industry and that for the farmers. The focus will lie on the preference formation by the industry bodies of both industries and examine how they translated into the government's economic policies. After the brief introduction, the article will give a schematic overview for the policy recommendations of the two rivalling economic bodies of thought, the 
orthodox and the heterodox economic schools in Brazil. Then the paper will proceed by introducing the domestic politics-approach as the theoretical frame, to derive explanatory variables for the foreign trade policies in Brazil. After this overview, the article will delve into the sources of the trade and industrial policies of two powerful domestic sectors, namely the automotive industry and Brazil's agriculture. The reconstruction has been accomplished by sifting through the media coverage, by conducting interviews and by consulting analyses by researchers. The article will be concluded by a crisp summary on the findings and will give a short outlook.

\section{THE NEW HYBRID MODEL IN BRAZIL'S TRADE AND INDUSTRIAL POLICY - THE PUZZLE}

Latin America and Brazil in particular has always been a breeding ground for "maverick economic analyses" that "dissent from liberal orthodoxy" (Whitehead, 2005 , p. 246). Liberal ideas or rather remedies conceived by an orthodox economic approach, however, gained momentum, when President Cardoso decided to rein in the out-of-control hyperinflation in the 1980s and early 1990s. This opened Brazil up for ideas stemming from the so-called Washington Consensus. This consensus epitomizes the neoliberal or orthodox policy prescriptions. Their ideas and proposed remedies were further buoyed by the appointment of rather orthodox economists such as the authors of the Real Plan to the helm of Brazil's public economic institutions. Among these influential and homegrown economists were many professors from the Economics-faculty of the Pontifícia Universidade Católica do Rio de Janeiro (PUC-RJ), such as Edmar Bacha, who became President of BNDES, Gustavo Franco, former President of the Central Bank and Lara Resende (Loureiro, 2009 , p. 128). But as soon as 2001, the tide had already turned and media reported that influential ministries, such as the Ministry of Development, Industry and Foreign Trade (MDIC) were pondering the idea of industrial policies and mulling over the idea of import substitution, without prompting opposition from once stalwart defenders of economic orthodoxy, such as the Ministry of Finance. ${ }^{1}$ While the presidential hopefuls for the 2002 presidential elections, from José Serra (PSDB) to Ciro Gomes (PPS) and Lula da Silva (PT) were tripping over one another to distance themselves from the "neoliberal" policies of the presidential predecessors, there was also a changing of the guard in the economic team of the subsequent administrations. As the growth prospects dimmed and the memories of the destabilizing hyperinflation started to fade, the old orthodox administrators were increasingly replaced with more flexible or heterodox economists, starting in the

${ }^{1}$ Valor Econômico , 5 July 2001. 
mid-2000s. This trend was accentuated in Lula da Silva's second presidency and Dilma Rousseff's first term (Loureiro, 2009, p. 134). ${ }^{2}$

This shows that there are two strong ideational currents regarding the formulation of economic policies. The next two sections shall discern the policy recommendations regarding trade policies, on which the representatives of the two strands coalesce, and identify recent policy measures that seem to correspond to the recommended archetypes of the two strands.

\section{The heterodox policy consensus for countering Brazil's De-Industrialization}

The developmentalist economic model up until the late-1980s has been shaped by the attempt to shed the alleged status of Brazil as a "semi colonial country" that still lingered in a state of "economic and cultural dependency on Europe and the US" (Kubitschek cited in Bates, 1999, p. 112). Under this economic model, the Brazilian government deliberately discriminated against Brazilian farmers and funneled the available resources and those expropriated from the agribusinesses to the nascent manufacturing sectors.

For Mr. Bresser-Pereira and others who uphold developmentalist ideas, the dependence on inflows of foreign capital is a threat to Brazil's sovereignty (Abu-El-Haj, 2007, p. 93). That is why the Developmentalists want to develop a stronger state and want to orient their economic policies along the lines of a consistent national development strategy (Morais and Saad-Filho, 2012, p. 3). This development strategy is to facilitate the transition from "low to high value added per capita industries" (Bresser-Pereira, 2011, p. 493). The goal is therefor to reduce the overdependence on unprocessed commodity goods and to make a decisive foray into more technologically sophisticated spheres of production. Therein tariff policies are considered a legitimate way to steer the economic development (Sikkink, 1991, p. 142). Part of the import-substitution policies - inspired by Developmentalism - are local content rules. In the car industry the domestic-content requirements were - in the past - to assure that an indigenous class of entrepreneurs was to arise, so as to keep value-addition in the country, but also to wean the Brazilian economy off the dependence on foreign multinationals and foreign capital (Shapiro, 1994, p. 195).

The "departures from orthodoxy" during Lula da Silva's second term, according to Ban (2013, p. 307) and Boschi (2014, p. 138) included tax measures for the car industry that had been part of Growth Acceleration Program (Programa de Aceleração do Crescimento - PAC). This sector-specific industrial policy was furthered in 2011 with the promulgation of the Greater Brazil Plan (Plano Brasil Maior), wherein the Brazilian government enunciated industrial policy measures directed at the automotive industry. This resonated with the ideas of heterodox economists. Arbix and Martin (2010, p. 16) see this as evidence that the Brazilian

\footnotetext{
2 This trend seems to reflect the structural tilt towards statist ideas, which left The Economist (28 January 2010) to gasp that in Brazil "economic liberals (...) are as scarce as snowflakes".
} 
government has not retreated "into a passive laissez-faire", but engages in trade negotiations to pro-actively change Brazil's terms of trade.

Other outspoken supporters of the new policy shift, however, while touting the infusion of new "elements of neo-developmentalism", remain unsatisfied that they coexist within the extant neo-liberal framework (Morais and Saad-Filho 2012, p. 792). The point of view of the critics of the neoliberal mode is captured in the following quote by Bresser-Pereira: "We are no longer in the national Developmentalism of the 1970s, but we have overcome the economic Liberalism of the 1990s, which ended in 2008. What remains to be done is to enter the new era of New Developmentalism." 3

\section{The orthodox policy consensus for countering Brazil's De-Industrialization}

Despite the above mentioned interventions of the Brazilian government, the relatively open trade regime has not been radically upended. The unilateral opening, which had been achieved in the early 1990s has been largely maintained. The Washington Consensus captured by John Williamson (1990, p. 15) generally recommends the liberalization of trade, but it is especially insistent to unilaterally raze custom duties on intermediate inputs and capital goods. This would promote exports, as it would allow the companies to increase their productivity and modernize their products and their production facilities. The Collor administration with reforming zeal slashed the custom duties on those goods which were not produced in Brazil, and they continued with the unilateral tariff cuts even for those goods that had a domestically manufactured equivalent (Kingstone, 2009, p. 111).

These unilateral tariff cuts have been furthered in some sectors even during Dilma Rousseff's term, who is said to harbor strong sympathies for the Developmentalist approach (Morais and Saad-Filho, 2012). To foster the development of the agro industry the government has tried to push for Free Trade Agreements (FTAs) that would whittle away the entry barriers for Brazil's agricultural produces in the overseas markets (Hopewell, 2014, p. 302). Moreover it has unilaterally razed the custom duties for agricultural inputs such as fertilizers, agrochemicals and seeds.

But economists like Edmar Bacha, who was one of the founding fathers and subsequently one of the core members of the Real Plan, but also international organizations, such as the OECD, have demurred at Brazil's relative economic isolation, as the economic integration has lagged behind because of the stalled economic reforms of Brazil's trade regime (Bacha, 2013, p. 5; OECD. 2013, p. 67). Thus in polar opposition to the Developmentalists, they call for unwinding the recent protectionist interventions, which remain the bete noire for them, and ask the government to deepen the cuts in the custom duty structure.

\footnotetext{
${ }^{3}$ Rede Brasil Atual, 26 August 2013.
} 
Table 1 : Schematic overview of the proposed political remedies against Brazil's De-Industrialization

\begin{tabular}{lll}
\hline \multicolumn{1}{c}{ Goal } & Neoliberal/Orthodox Remedies & Developmentalist Remedies \\
\hline $\begin{array}{l}\text { Increasing } \\
\text { Competitiveness }\end{array}$ & $\begin{array}{l}\text { Increase cost competitiveness } \\
\text { through horizontal measures }\end{array}$ & $\begin{array}{l}\text { Design a National } \\
\text { Development Strategy }\end{array}$ \\
& $\begin{array}{l}\text { Primary Goal: Cost competitiveness } \\
\text { - Reduce tariffs on intermediaries }\end{array}$ & $\begin{array}{l}\text { Primary Goal: Preserving } \\
\text { employment }\end{array}$ \\
- No local content requirements & $\begin{array}{l}\text { - Temporary trade protection } \\
\text { - Against distorting non-tariff } \\
\text { barriers }\end{array}$ & $\begin{array}{l}\text { Preserve value addition, incl. } \\
\text { backward linkages }\end{array}$ \\
& $\begin{array}{l}\text { Increase competition in the do- } \\
\text { mestic markets by removing entry } \\
\text { borriers }\end{array}$ & $\begin{array}{l}\text { Increase competition } \\
\text { between domestic producers }\end{array}$ \\
\hline
\end{tabular}

\section{THE DOMESTIC POLITICS APPROACH TO EXPLAIN FOREIGN ECONOMIC POLICIES}

In the late-1970s Peter Katzenstein (1978) turned towards domestic politics, to explain the diverging patterns in each country's foreign economic policy. According to him, the policies adapted by the governments reflected the respective societal pressures. This "osmosis of state and society" is also recognized by Andrew Moravcsik's more refined Liberalism theory. Moravcsik (1997, p. 524) argues in the same vein, proposing ideational and commercial pressures as two of the factors that might shape the state's preferences. According to Moravcsik, foreign trade regulations could be shaped by ideational convictions in the form of "local social compromises concerning the provision" of shelter from the global markets or the untrammeled access to them, or they could be an outflow of materially motivated "market incentives facing domestic and transnational economic actors".

The Societal Approach, by Stefan Schirm (2013a), shines the light on the circumstances, which make the prevalence of either interests or ideas in shaping the preferences of the government more plausible. Within its framework one can pit the explanatory power of both strands against one another. The societal approach extensively operationalizes the ideational and interest-based motives, to verify whether either one of them determined the political outcomes.

Based on Schirm's (2013b, 2009) theoretical and empirical investigations the article will therefore test if material interests, by the directly affected industries, trump economic ideas.

\section{H1: Interests prevail over ideas, if the trade policy affects specific sectors.}

This emanates the question, how interests could shape Brazil's trade policies. Here, economic theories can help in deducing a first hypothesis. The specific factors 
model allows production factors to be permanently lashed to a certain sector (Krugman and Obstfeld, 2003). The model relaxes the assumption of perfect mobility of factors, which can be redeployed to other usages in the wink of an eye. The specificness of a factor impedes its mobility and depends on the time and costs it takes for it to be redeployed to other usages. The implications on how specific factors will position themselves vis-à-vis general economic policies have already been described by Frieden (1991). Regarding the efforts to promote freer trade, the theory establishes benefits arising to those factors invested in sectors that are competitive and achieve trade surpluses. Factors specific to industries under pressure will on the other hand suffer and hence beset the government to refrain from lowering entry requirements. The theory is simply to show that each sector faces different competitive pressures and that the industries will develop sector specific preferences.

This would thus allow for a variegated outcome of the trade policies in the same country, with the growing possibility of trade barriers, if the industries were uncompetitive.

\section{H1.1: The uncompetitiveness of an industry determines whether or not the industry will lobby for protection or not.}

But this does not explain the unilateral tariff cuts that have paralleled the new protectionist state interventions. In this regard, the crucial driving force of the industries' lobbying with regards to the government's foreign economic policies is the unwillingness of the domestic industries to tolerate the distortionary effects of protectionist manoeuvres. This unwillingness is in marked contrast to the tolerance exhibited in the years of the import substitution models in Brazil. While one can safely assume that the distortionary effects of protectionist interventions have remained the same over time, the aggrieved domestic industries are no longer placated by the government. In the past decades, the cosseted industries were granted guaranteed prices. That means they could charge a guaranteed price that amounted to their incurred costs and a profit margin. In Brazil, the government formed an Interministerial Price Council (CIP), where the firms and industries were to submit their cost plans, to get approval for price increases. While this system was implemented to keep prices in check, its independence was increasingly corroded and politicized by the business interests (Kingstone, 1999, p. 57). It degenerated into a self-service shop, when the assemblers were allowed to raise the prices before consulting the price council. The system had therefore essentially become one of "institutionalized markup pricing" in favour of the producers (Shapiro, 1994, p. 201). Hence many of the Brazilian companies could simply roll over the policy-induced inefficiencies, by charging higher prices from its customers.

The reforms in the 1990s, however, rid the economies of the planning system. A more competitive environment makes sure that the tacit reciprocal support between the state and the industries and politically potent conglomerates is hampered. Thus one can expect that first of all a debate will arise between the different firms and sectors and that each industry will try to remain competitive, as the competition has become unrelenting. This will increase the efficiency pressures on every 
industry, regardless of its competitiveness, and make them ardent supporters of freer markets.

\section{H1.2: The dependence on foreign inputs, intermediate}

and capital goods will make the industries lobby for free trade.

To test these above posited hypotheses, the paper will juxtapose the lobbying of two different industries, with varying degrees of competitiveness. More specifically it will examine the lobbying of the relatively uncompetitive car complex, which has been buffeted by imports gushing in from East Asia, and compare it with preferences of the agribusiness, which has seen its exports surge to hitherto unprecedented levels.

\section{EXPLAINING THE ORTHODOX POLICIES IN BRAZIL'S AGRIBUSINESS}

The channel between the agricultural associations and the government's agenda

In interviews, the representatives of the Brazilian farmers' associations complained over the ideological bias of the rather left-leaning Worker's Party against the farmers. Nevertheless, the agricultural sector is able to influence the executive's agenda through the Ministry of Agriculture, the MAPA (Ministério da Agricultura, Pecuária e Abastecimento). João Roberto Rodrigues, who had been Minister for Agriculture between 2003 and 2006, described his task as having to "bring home (i.e. to his farmers) the (financial) bacon" (US cable, 2006). After he had failed to change, what the agribusinesses considered the greatest evil, "Lula's government's neglect of their field", he resigned. ${ }^{4}$ The strong ties between the minister and the farmers is strengthened by the fact that many ministers, such as Mr. Rodrigues or the current Minister for Agriculture, Kátia Abreu, used to preside over agricultural associations (Hopewell, 2014, p. 299)..$^{5}$

While the farmers' peak association, the CNA (Confederação da Agricultura e Pecuária do Brasil) are interested in thrusting their demands on the ministry's and subsequently the government's political agenda, smaller more specific associations seek to collaborate closely on the technical level with the MAPA to tweak policy regulations in their favour, by furnishing information, drafting policy proposals and hammering out and filling in the technical details of the political projects.

Beyond the federal government, the agricultural associations can rely on the Congressional Caucus of Agriculture, the FPA (Frente Parlamentar da Agropecuária), which consists of over 200 members in the Congress or the Senate. Their members come from all parties and from all regions and are organized in a hierarchical way. While the representatives of the agricultural industry in Brazil have been

\footnotetext{
${ }^{4}$ Valor Econômico, 29 June 2006.

${ }^{5}$ Interview.
} 
critical of the deputies' allegiance to their respective parties, they have all lauded the loyalty and the discipline of the members of the FPA. Like the CNA, the FPA, which has been called Brazil's $3^{\text {rd }}$ largest party (Simionatto and Costa, 2012), has implemented a program that allows the parliamentary caucus to monitor all the relevant legislation in a systematic way (Machado, 2013). The emergence of the FPA was fostered by the financially potent soy industry (Richardson, 2012, p. 94). The presidents and the members of the congressional caucus have served as unofficial spokespersons of the agribusinesses. That is why the farmers' associations no longer have to contact the PT-administration directly, which is - according to the representatives of the farmers' associations - wary of farmers' interests.

\section{How the soybean farmers flourished after the liberalization of the economy in the 1990s}

The stellar ascent of the soy growers had been enabled through the market reforms in the early 1990s. During the import-substitution decades, resources were siphoned off the primary sectors and funnelled to industries, which had been deemed vital for Brazil's economic growth. The farmers on the other hand were barred from state funds and subjected to discriminatory fiscal practices (Bates, 1997, p. 112). The deliberate discrimination of the farmers and consequently that of the soy growers was upended with the Plano Real in the early 1990s. The reform blueprint weeded the discriminatory taxing practices out (Monter, 2004, p. 154).

The Plano Real also entailed the unilateral reduction of the prohibitively high custom duties on crucial agricultural inputs in the early 1990s. Immediately after the import barriers had been razed, the Brazilian soybean growers ceased the opportunity and dramatically increased their purchases of foreign fertilizers, pesticides and agricultural machinery (Schnepf et al., 2001, p. 45).

Another important boost for the Brazilian soybean growers comes from the access to foreign technology in terms of genetically engineered seeds provided by the US-multinational Monsanto. The seeds developed by Monsanto are called "Roundup Ready" and are designed to withstand the detrimental effects of herbicides, such as Glyphosate, thus allowing farmers to destroy weeds by indiscriminately spraying the herbicide Glyphosate on their fields, leaving the soy plans unscathed (Rivoli, 2009, p. 43).

The elimination of the discriminatory taxation of the raw goods in Brazil, as well as the productivity spurts and the expansion of the arable land sparked a surge in the exported value.

But the Brazilian farmers are suffering from high costs on its inputs. In the segment of agrochemicals and in that of fertilizers, the Brazilian farmers have a strong competitive disadvantage over the US-farmers, as the latter pay far less for the necessary fertilizers and the pesticides (Leibold and Osaki, 2010, p. 10).

According to one representative of CNA, one of the most important priorities was to lower the prices for agrochemicals and fertilizers. While the farmers in the South were especially keen on lower prices for herbicides, due to the fertile soil, the 
new farms cropping up in the new agricultural frontier in Brazil's centre-west were dependent on lower prices for fertilizers, to compensate the soil's poorer quality. From this vantage point, the agricultural associations set out to formulate its policy preferences and shape the government's policies.

\section{How the farmers' preferences for free access to Glyphosate translated into free trade}

With the spreading use of transgenic crops in Brazil, which could resist the corroding effects of certain kinds of herbicides, Monsanto could in parallel snap up the largest chunk of the herbicide market segment, as it had also developed and patented the fitting agrochemical, Glyphosate. Subsequently Glyphosate conquered an ever-increasing share of the market as the use of genetically modified seeds proliferated. It was expected that Glyphosate would soon represent half of the herbicides sold in Brazil. ${ }^{6}$

The company paralleled its marketing activities in Brazil with the building of two factories, which churned out the Glyphosate needed for the Brazilian market. After these investments the company was considered a domestic industry by the Brazilian Ministry of Development, Industry and Commerce (MDIC) (Filomeno, 2014, p. 77). In 2001, however, Monsanto's patent for Glyphosate expired. This was exploited by chemical companies in China that emulated and copied the formula of the active ingredient in Glyphosate. Brazil's farmers were thus eager to purchase the generic version of Glyphosate, furnished by the Chinese petrochemical industry. But Monsanto, to uphold its profit margins, filed an anti-dumping investigation with the MDIC and in February 2003 the Brazilian government sanctioned anti-dumping duties as high as 35.8 per cent on Chinese Glyphosate (ibidem, p. 76).

With the introduction of the anti-dumping duty, the Brazilian government had virtually sealed off the herbicides market from imports. Moreover, there were regulatory barriers, which snarled up the registration process of generic agrochemical versions. Even if the generic version used the exact same formulas and ingredients as the product that had run off-patent, they would still have to go through a clearing process with agencies of the Ministries of Health and Environment. These expensive processes could easily drag on for years.

This led to the fact that imports of Glyphosate and generic versions thereof stood at essentially zero, until the agricultural business associations started to protest the government's protectionist policies. ${ }^{7}$ But the conflict line did not run between an autonomous government and the agribusiness, but rather between the latter and the interests of Monsanto. The agricultural associations blamed a "monopoly of multinational companies" as the main culprit in barring the farmers' access to generic versions from China. ${ }^{8}$ With these statements they were sniping at

\footnotetext{
${ }^{6}$ Gazeta Mercantil, 20 October 2003.

${ }^{7}$ Gazeta Mercantil, 20 October 2003.

${ }^{8}$ Gazeta Mercantil, 7 August 2007.
} 
Monsanto that - according to CNA, - furnished 90 per cent of the available Glyphosate in Brazil and had monopolized the market segment. ${ }^{9}$

In May 2006, CNA published a survey in which the industry body's members saw the escalating prices for their inputs and especially those of the agrochemicals as the main culprit of their financial distress. ${ }^{10}$ Subsequently CNA zeroed in on the goal of easing the access for generic versions of the active ingredients of Glyphosate into the country to eventually lower the prices of pesticides in Brazil. At that time the regular registration requirements in Brazil implied that the application process could take up to five years, thus hindering the free imports of Glyphosate even from the other Mercosur countries. This resulted in a price differential of 50 per cent between Argentina and Brazil for the same products. Ricardo Cotta, CNA's former technical superintendent, said that he would use this as an argument with MAPA and its minister. ${ }^{11}$ Within MAPA, CNA, first of all pressed to change the working group responsible for the area of herbicides that had - according to Mr. Cotta close ties with Brazil's agrochemical industry. After it had replaced those bureaucrats with more trustful officials, they formulated a proposal that was based on international standards that had been proposed by the Food and Agriculture Organization (FAO), which would essentially reduce the time of their approval.

Moreover, the industry garnered more support for its plans, by convincing Brazil's Finance Minister, Guido Mantega, to back the plan. As the minister was already in a campaign mood for the up-coming elections in October 2006, he re-assured his sympathy to the sector during a public hearing in the National Congress. While pledging to roll out financial packages, he also contended that the "streamlining" of the import process of generic pesticides should be possible and that he saw "no difficulty in doing this". ${ }^{12}$ With the support of both ministries, the industry was able to face down the opposition from other quarters of the government, namely that of the Ministries of Environment and Health. Moreover, they worked closely together with Tereza Campello, at that time the Assistant Deputy Chief of Staff, who has been described as close advisor of the influential Chief of Staff, Dilma Rousseff. At that time Mrs. Campello headed the task force charged with improving the competitiveness of Brazil's agricultural products by upping the supply of pesticides. ${ }^{13}$ While the CNA has been attributed of having furnished the technical know-how, they could rely on the political pressure exerted by Mrs. Campello and the Minister of Agriculture, who according to representatives of the industry, were a constant reminder to the President and his staff of the costs incurred by five million farmers to the benefit of the monopolist Monsanto.

In December 2006, the supporters of the loosening of the regulatory barriers managed to circumvent the domestic opposition, by letting the Brazilian President,

\footnotetext{
${ }^{9}$ Valor Econômico, 19 December 2007; Interview.

${ }^{10}$ Gazeta Mercantil, 16 May 2006.

${ }^{11}$ Valor Econômico, 10 July 2006; Interview.

12 Valor Econômico, 1 June 2006.

${ }^{13}$ Interview; Canal do Produtor, 5 December 2006.
} 
Lula da Silva, issue a presidential decree. The decree dislodged the opposing ministers from the legislative process. ${ }^{14}$ This was achieved by allowing producers of generic versions based on active ingredients that had already been registered in Brazil, to simply go through an automatized computer system. This reduced the average time between the date of the application of a generic agrochemical and its registration from up to five years to six months. ${ }^{15}$

But the imported volumes of Glyphosate remained moderate as long as the punitive dumping duties remained in place. The impetus for attacking the anti-dumping duties came after Monsanto had upped the prices by over 85 per cent within a year. ${ }^{16}$ Subsequently, the agribusiness associations pulled the anti-dumping duties more decisively into the limelight of the political debate, by railing against the purported overpricing by the US-multinational. In August 2007, CNA's technical superintendent, Ricardo Cotta, named the abolishment of the anti-dumping duties on Glyphosate and nitrate in a public hearing of the Congress as the number one priority of his association. He said that the price was too high, "to benefit only one company", thereby clearly attacking Monsanto. ${ }^{17}$ When Monsanto again raised the price on Glyphosate, CNA repeated its accusations vis-à-vis Monsanto and called for allowing imported pesticides to enter the market. ${ }^{18}$ As the agribusiness stepped up its consultations with the different ministries, the Brazilian Foreign Trade Board, Camex, decided to review the punitive duties. Although the intra-ministerial board is headed by the MDIC, which exhibits a clear and proven track-record of being sympathetic to the processing units in Brazil, the agribusinesses could influence the bickering through the Ministry of Agriculture, which had a seat and a veto right in Camex. In February 2008, Camex decided to lower the anti-dumping duty from 35.8 per cent to 11.7 per cent. The complete abolition was thwarted by the industry body representing the Brazilian Glyphosate producers, Sindag as well as Monsanto that greeted the decision to maintain the anti-dumping duties. ${ }^{19}$ The most important argument of Monsanto rested on the investments it had undertaken to build up its glyphosate manufacturing unit in Bahia, which was used by Monsanto to pressure the MDIC. Throughout the bickering over the rate of the anti-dumping duties, Monsanto had cautioned the ministry that it would stop its local production activities, unless it would be granted protection from the lowerpriced Chinese generics.

After another round of cuts in the applied anti-dumping duties on Glyphosate, which were slashed to 2.9 per cent, Monsanto attempted to re-introduce the anti-dump-

\footnotetext{
${ }^{14}$ Agra-net, 26 October 2007; Interview.

15 Valor Econômico, 23 April 2007; Canal do Produtor, 6 February 2007.

${ }^{16}$ Valor Econômico, 23 April 2007.

${ }^{17}$ Jornal do Commercio, 15 August 2007.

${ }^{18}$ Valor Econômico, 19 December 2007.

${ }^{19}$ Gazeta Mercantil, 13 February 2008.
} 
ing tariffs. ${ }^{20}$ But the initiatives floundered as the agricultural associations staunchly opposed the moves. Political figures that were closely aligned with the ruralistas, such as Congressman Carlos Heinze denounced any further attempts by Monsanto to re-introduce the anti-dumping duties. He harshly criticized the constant pressure exerted by the US-multinational on the Ministry of Development (Filomeno, 2014, p. 76). The negotiations dragged on for a year and were terminated when Monsanto decided to withdraw the case lodged with the Brazilian government in August 2011. ${ }^{21}$ As Monsanto had relented on this matter, the government could now - at the behest of the agribusinesses - end the anti-dumping duty on Chinese glyphosate. This was decided on July 2013 and eradicated an important Brazilian trade impediment. ${ }^{22}$

Table 2: The domestic sources for the formulation

of orthodox policies in the agricultural sector

\begin{tabular}{|c|c|c|}
\hline Priority by the farmers & Intermediary in the government & Government's orthodox policies \\
\hline \multicolumn{3}{|l|}{ Pesticides } \\
\hline $\begin{array}{l}\text { July 2006: Ease registration of } \\
\text { generic versions of } \\
\text { agrochemicals }\end{array}$ & $\begin{array}{l}\text { Pushed politically by the } \\
\text { Ministry of Agriculture }\end{array}$ & $\begin{array}{l}\text { December 2006: Presidential } \\
\text { Decree - Automatized } \\
\text { registration }\end{array}$ \\
\hline $\begin{array}{l}\text { April 2007: Abolish } \\
\text { Anti-Dumping Duties (ADD) on } \\
\text { Glyphosate }\end{array}$ & $\begin{array}{l}\text { The Ministry of Agriculture secon- } \\
\text { ds them within CAMEX }\end{array}$ & $\begin{array}{l}\text { February 2008: CAMEX lowers } \\
\text { the ADD from } 35 \text { to } 11 \text { per cent }\end{array}$ \\
\hline $\begin{array}{l}\text { August 2011: Monsanto stops } \\
\text { asking for ADD on Glyphosate }\end{array}$ & & $\begin{array}{l}\text { July 2013: CAMEX abolishes the } \\
\text { ADD on Glyphosate }\end{array}$ \\
\hline
\end{tabular}

\section{Fertilizers}

November 2004: Complaints

over the prices for fertilizers

\section{January 2007: Stimulate competition by expanding domestic production capabilities}

July 2013: No custom duties for fertilizers to incentivize investments
May 2008: Priority of the Ministry of Agriculture June 2008: Picked up by President Lula da Silva - Pressure on Vale and Petrobras

Support by the Ministry of Agriculture against the demands by the petrochemical industry
August 2005: Custom duties on fertilizers are halved to 2 per cent

2011/2012: Vale and Petrobras unveil plans to expand their production capabilities

Fertilizers have remained on the CET-exemption list

\footnotetext{
${ }^{20}$ Valor Econômico, 16 January 2009.

21 antidumping.vn, 27 August 2011.

22 The question on why Monsanto relented remains unclear (Agra-net, 3 July 2013). Filomeno (2014, p. 77) speculates that the multinational beat a tactical retreat, to obtain concessions in the field of intellectual property.
} 


\section{CONCLUSION}

The industrial as well as the foreign economic policies in the above described product segment have been shaped by the weariness of the farmers' associations over monopolistic situations and cartel formations in their supply chain. They sought to stimulate the competitive pressure, by prodding the government to allow unhampered access to imported fertilizers, pesticides and seeds. Furthermore, it sought to expand the domestic production capabilities to eventually erode the pricing power of the overseas suppliers and domestic monopolists, by widening the supplies. Due to their strong influence, which it could exert through the Ministry of Agriculture and the allegiance of the Frente Parlamentar da Agropecuária (FPA) in the Senate and in the Congress, it managed to impress their policy preferences on the government's policies. Despite the ideological pre-disposition of the Worker's Party administration for re-industrializing Brazil, the associations warded off attempts to re-impose custom duties on their supplies and avoided that the government gave in to the infant industry argument put forward by the respective industry bodies. The economic outcomes of the "orthodox" industrial policies have been mixed.

In the Glyphosate market, the agricultural associations were happy to see the prices for Glyphosate - offered by Monsanto - shrink from $\$ 12$ to $\$ 8$ per kilogram, after the government's decision to allow imports (CCM Information Science and Technology, 2012, p. 5). Although there are reports that some domestic producers of the herbicide had to exit the market, Monsanto has so far retained its production capabilities in Brazil, even though the plant manager located in Bahia reported that the idle capacity had increased by 20 per cent (ibidem, p. 6). Instead of closing down the production capabilities, as threatened after the Brazilian government had abolished the custom duties, Monsanto decided to review its brand portfolio, increased investments into $\mathrm{R} \& \mathrm{D}$ and rationalized its internal processes, in order to be able to compete with the Chinese imports.

\section{EXPLAINING THE HETERODOX POLICY RESPONSES FOR THE CAR PARTS INDUSTRY}

\section{The channel between the car complex and the government's agenda}

Within the government, the industrial manufacturing industries have strong allies within the MDIC and the Ministry of Planning. The ranking mandarins in both ministries are preoccupied with propping up Brazil's industrial growth. They are thus very receptive to arguments regarding Brazil's need for further industrialization and promises of investments by business groups or trade associations (Gómez-Mera, 2007, p. 119). The car industry in particular has forged a strong political representation. Especially the car assemblers, represented by Anfavea, are said to have direct personal access to policy-makers via "personalistic contact with 
state actors in bureaucratic rings" (Doctor, 2007, p. 126). These connections seem to have lived on, even after many cozy ties between private industries and the state had been swept away after Brazil had sloughed off its Developmentalist model in the early 1990s. This is helped by the fact that the car industry has always been perceived as the poster child of Brazil's industrialization, epitomizing the great strides that Brazil had made, turning from a coffee grower to a quickly industrializing regional power (Sikkink, 1991, p. 138).

Furthermore the topic of establishing a staunch car industry in Brazil still has a lot of electoral traction. Thus the car complex has the attentive ear of the Brazilian government up into the presidential office, giving it prodigious influence in comparison to other industry bodies (Navarro et al., 2013, p. 559). Sindipeças, the association representing the car parts manufacturers, by contrast feels that it is put in second place by the government (Kingstone, 1999, p. 84). Unlike the oligopolistic car assemblers, the suppliers have a splintered market structure, where many indigenous smalland medium sized companies struggle to earn their keep in the face of growing competition from East Asia, while the so called tier-1 suppliers, as multinational mammoths with their Brazilian subsidiaries, exert pressure on their suppliers and try to broaden their supplier base, by opening the import channel. This bifurcation of the industry has hindered their political representation and weakened their voice in the government. Complaints over the government's preferential treatment of Anfavea and the frustration over Anfavea's vetoing power have therefore been ubiquitous in their public statements and were vented in interviews.

\section{The state of Brazil's car industry}

The Brazilian automotive industry was built from scratch starting in the mid1950s. The local car industry soon became one of the most prized symbols of Brazil's modernization process and was one of the centrepieces of the so called Targets Program, which was to propel Brazil's industrialization (Sikkink, 1991, p. 138; Bergsman, 1970, p. 127). The automotive regime was implemented by luring foreign assemblers into the country. To that end the Brazilian market was almost completely isolated from foreign imports. This assured the foreign multinationals in the Brazilian market that they could skim generous profits from their sold units, which were explicitly tolerated by the Brazilian government. ${ }^{23}$ The requirements to enter the Brazilian market encompassed demanding and ambitious local content rules. Within a few years, the Brazilian government raised the local content quota to 95 per cent, which amounted to an abrupt cut-off from foreign imports. This led to the establishment of the Brazilian car parts industry (Shapiro, 1994, p. 195).

\footnotetext{
${ }^{23}$ Rampant inflation in the 1950s led to a parliamentary inquiry about the high prices for Brazilian cars. The commissioned report by the government, however, deemed the high prices and high profit margins as necessary to stimulate investments and production levels in the Brazilian auto industry (Shapiro, 1994, p. 198).
} 
The Brazilian reforms in the 1990s on the other hand led to considerable changes. Before the partial liberalization of Brazil's car market, the industry for car parts was strongly fragmented and many small and medium-sized manufacturing units thrived due to the prohibitively high custom duties and the local sourcing requirements. ${ }^{24}$ Immediately after the competitive pressures started to encroach on the industry, many Brazilian companies and entrepreneurs simply left the market. The outcome was, what critics called, a rapid de-nationalization of the auto parts industry. Within four years, the ownership structure in the industry was upended, with foreign shareholders dominating the industry from 1997 onwards (Posthuma, 2005, p. 35).

\section{The arrival of the Chinese and the fight against the discount on custom duties for car parts}

In order to break the hyperinflationary spiral that had fed from ever-increasing prices on goods and salaries, the administration sought to enhance the stabilization of the prices, by fueling competition through lowering import barriers. Trade policy was therefore subordinated to the overarching goal of achieving price stability (Gómez-Mera, 2007, p. 121). Thus only the assemblers of cars - as arguably the most politically potent industry - had been exempted from the thorough razing of import tariffs. Complaints and calls for protection by the foundering car parts industry by contrast were not abetted by the government, which pointed out that the macroeconomic stabilization was not yet cemented..$^{25}$

With this steadfast commitment, the government pre-empted lobbying efforts by the industry. The restructuring pains by the suppliers were, however, assuaged via an informal local content rule that forced car assemblers in Brazil to source 60 per cent of their components from Brazil-based factories, if they wanted to obtain loans by the BNDES. This allowed the car suppliers to coast in the tailwinds of the debt-fueled domestic demand. In February 2001, the introduction of a provisional measure that introduced a 40 per cent deduction on the custom duties paid for imported auto components, roused limited attention with the car parts association. ${ }^{26}$ This rebate reduced the effective custom duties on car parts from 14 per cent and 18 per cent to only 8.4 per cent and 10.8 per cent. Unnoticed by the industry, this provisional measure even turned into law as the Congress had decided to turn provisional measures into law, if the measures were not rejected within a certain time frame. ${ }^{27}$ Thus they became set in stone almost by accident and were barely noticed by the industry.

\footnotetext{
${ }^{24}$ This system earned some companies handsome returns on equity that figured at above 20 per cent for some of the car parts manufacturers.

${ }^{25}$ Exame, 3 July 1996.

${ }^{26}$ This policy was tailored to the demands of the car assemblers, as retailer, who would not process the cars parts, but rather resell them continued to pay the full custom duties, without the rebate of 40 per cent.

${ }^{27}$ Valor Econômico, 3 February 2006.
} 
The benign neglect of the barriers for imports changed with the rise of the Asian competitors. The worries over China as a competitor were fuelled by the dynamism, by which China started to substitute imports through strong investments by foreign multinationals. Its ascent was likened to the rapid ascent of South Korea and Japan, only that China had an even vaster population, thus being more ready to emulate and outstrip the low-cost strategy steered by Brazilian companies. The Chinese companies thus encroached on those - rather low-tech - product segments, where Brazilian producers had carved out a niche for themselves. ${ }^{28}$

At the same time, however, as the small- and medium sized companies were increasingly threatened by the Chinese exports, some companies in the supply chain, the so called tier-1 suppliers, which sell the fully assembled modules to the car assemblers, are interested in broadening their supplier base. This stratified supply chain has seriously hampered the political representation of the car parts industry. ${ }^{29}$ While Paulo Butori, president of Sindipeças, in 2005 for the first time clamoured the government to abolish the 40 per cent rebate on the custom duties paid for imported car parts, the business association was bogged down and paralyzed by an internal conflict over the issue. As the industry had bifurcated, they could not pursue and present their case coherently. This changed, when the industry in 2009 for the first time since 2002 posted a substantial trade deficit. But still, instead of lobbying the government, Sindipeças' president was preoccupied to stitch together a common stance of the industry, which reportedly took him six months. ${ }^{30}$

As Mr. Butori signaled that this trend would likely accentuate over the coming year, the industry finally consolidated its stance and in April 2010 it came through to the government. With their expected trade deficit of $\$ 3.6$ billion, the industry managed to get the attention of President Lula da Silva, who was said to be personally concerned over the widening trade deficit in the auto-parts industry and in the electronics sector. ${ }^{31}$ After the president's nod, the option to delete the 40 per cent rebate on the custom duties paid for car parts, soon circulated in the government as a short-term remedy against the widening trade deficit. So, just after Sindipeças had eked out a common stance and with the tailwind of the looming elections, the government started to ponder the idea of razing the rebate of 40 per cent on the custom duties. ${ }^{32}$ On 28 April, the car parts segments revved up the pressure on the government, by rallying the labour unions to their banner - including the largest and most important labour federation, the Unified Centre of Workers (Central Única dos Trabalhadores - CUT) - and by including other business associations,

\footnotetext{
${ }^{28}$ Valor Econômico, 7 December 2005.

${ }^{29}$ Valor Econômico, 15 April 2010.

${ }^{30}$ Ibid.

${ }^{31}$ Valor Econômico, 15 April 2010; O Estado de S.Paulo, 14 April 2010.

32 Valor Econômico, 15 April 2010.
} 
such as the influential Brazilian Association of Machinery and Equipment, Abimaq. ${ }^{33}$ Together they protested the 40 per cent rebate and alleged that its existence threatened the jobs of 30.000 employees in this sector.

This move prodded the Ministry of Development to promulgate its decision to incrementally phase out the 40 per cent rebate for the car assemblers. Although the Finance Minister still had some objections, the government decided in May 2010, to stop the reduction in the tariff rates and to revert to the levels, applied prior to $2001 .{ }^{34}$ This in turn galvanized the opposition of the car makers, under the leadership of Anfavea.

Miguel Jorge, the Minister of Development, Industry, and Foreign Trade, apathetically delegated the finding of a compromise to the two business associations and told them they had thirty days to settle their dispute. ${ }^{35}$ The policies that ensued afterwards were therefore essentially the result of the haggling between Anfavea and Sindipeças. The protests by the auto assemblers were tempered by Sindipeças, which offered that it would collate a list of those products that were not produced in Brazil and could therefore be imported without any import duties. With this tactic, it countered Anfavea's argument that the rise in the effective custom duty rates would lead to rising prices for cars and therefore stoke inflation. This gambit blunted the confrontation between the upstream and the downstream industry and allowed Sindipeças to insist on a stamping out of the 40 per cent rebate. Moreover, Sindipeças and Anfavea presented a list of 116 components that should be imported duty free. As both Anfavea and Sindipeças supported the latter demand after their truce, the government heeded to them and in September 2010, Camex, the Brazilian Foreign Trade Board, promulgated that the custom duties on the components, tabled by the two business associations, would be reduced to 2 per cent.

Only five months after the full tariffs on imports had been reinstated, Sindipeças remarked that the import stream had barely been dented by this move and projected a growing chasm in the trade balance for the next years, with China snapping up an ever increasing market share. ${ }^{36}$ Moreover, the maneuver by the car parts industry had further strained the already terse commercial relations between the car assemblers and their suppliers. Bitter disputes, stemming from their mutual mistrust, spilt out into the media that showed the staunch opposition of the car assemblers against import barriers for their supplies.

\footnotetext{
33 O Estado de S. Paulo, 28 April 2010; Valor Econômico, 29 April 2010.

${ }^{34}$ O Estado de S. Paulo, 7 May 2010.

${ }^{35}$ Valor Econômico, 17 June 2010.

${ }^{36}$ Valor Econômico, 19 October 2010.
} 
Table 3: The sources of the national development strategy for the Brazilian supply chain in the car industry, Inovar-Auto

\begin{tabular}{|c|c|c|}
\hline Priority by the car industry & $\begin{array}{l}\text { Intermediary in the } \\
\text { government }\end{array}$ & $\begin{array}{l}\text { Government's heterodox } \\
\text { policies }\end{array}$ \\
\hline $\begin{array}{l}\text { April 2010: Abolish the } 40 \text { per } \\
\text { cent rebate on custom duties } \\
\text { for car parts }\end{array}$ & $\begin{array}{l}\text { Support by President Lula da } \\
\text { Silva and the MDIC }\end{array}$ & $\begin{array}{l}\text { May 2010: The rebate is being } \\
\text { razed }\end{array}$ \\
\hline $\begin{array}{l}\text { April 2011: Solicits help by } \\
\text { the government in incentivi- } \\
\text { zing innovation and invest- } \\
\text { ments }\end{array}$ & $\begin{array}{l}\text { Labor unions and business } \\
\text { associations form an alliance }\end{array}$ & $\begin{array}{l}\text { August 2011: The government } \\
\text { proposes to reduce the } \\
\text { sales tax for cars, if the } \\
\text { producers fulfill local content } \\
\text { requirement }\end{array}$ \\
\hline $\begin{array}{l}\text { August 2011: Refutes the } \\
\text { proposal and solicits short- } \\
\text { term remedies against } \\
\text { imports }\end{array}$ & & $\begin{array}{l}\text { September 2011: The } \\
\text { government increases the } \\
\text { sales tax for cars that do not } \\
\text { meet the local content quota }\end{array}$ \\
\hline $\begin{array}{l}\text { November 2011: Make the } \\
\text { local content rule more } \\
\text { restrictive, by making them } \\
\text { cost-based }\end{array}$ & $\begin{array}{l}\text { Sparring between car } \\
\text { assemblers and their } \\
\text { suppliers }\end{array}$ & $\begin{array}{l}\text { April 2012: The government } \\
\text { changes its local content } \\
\text { rules to a cost-based system }\end{array}$ \\
\hline $\begin{array}{l}\text { September 2012: Curtail } \\
\text { imports from China via } \\
\text { Argentina, by introducing } \\
\text { a traceability-project or by } \\
\text { increasing the custom duties } \\
\text { on car parts }\end{array}$ & $\begin{array}{l}\text { Sparring between car } \\
\text { assemblers and their } \\
\text { suppliers }\end{array}$ & $\begin{array}{l}\text { September 2013: The } \\
\text { government announces the } \\
\text { Inovar-Pecas package that } \\
\text { includes a traceability project }\end{array}$ \\
\hline
\end{tabular}

\section{GENERAL CONCLUSION}

The neoliberal policies have been the outcome of the analysis of the cost-structure by different industries and companies, rather than part of an ambitious micro-economic reform package by the government. To lower the break-even costs they prodded the government towards substantial unilateral tariff cuts in the upstream industries. This explains why there have been nearly as many liberalizing as protectionist policies in Brazil as a response to the global financial crisis (Gawande et al. 2011, p. 40). This lobbying explains why the "neoliberal" piecemeal deregulations of imports have been continued by the Workers' Party in Brazil, despite its presumed ideological penchant towards developmentalist ideas.

The exhibited opposition of the car assemblers against higher custom duties also explains the broader capping of the average tariff rates in Brazil. As the domestic industry sneered at the quality, the reliability and the prices of domestic 
supplies, it warded off higher custom duties in many instances or obtained concessions by the suppliers that exempted other upstream products from custom duties. The lobbying of the domestic industries thus corroborates Hypothesis 1.2 and explains why the import channel in Brazil has remained fairly open, as domestic industries staunchly defended the benefits that they derive from freer markets. But of course this way of letting the trade regime degenerate into a playing field between the different domestic industries leaves Brazil's trade policy riddled with exemptions and loopholes. The resulting policy maze, pocked with exemptions and riders, is certainly not what the proponents of the orthodox economic strand have in mind, when they propose a liberalizing overhaul of the trade regime.

The case studies also show that the industries beset by foreign competitors will solicit protection from the government, which substantiates Hypothesis 1.1. The demands by the industries gained traction, the bigger the trade deficits became and when the industry bodies could construct an understanding with the labour unions and levy the potential losses in employment with the administration. Under these circumstances, the government jettisoned its own policy templates and fickly conceded the fleshing out of the proposals to the business associations. This has been vividly demonstrated by the bickering over the Inovar-Auto rules.

The resulting stopgap measures have been driven by the priorities of domestic industry groups with political heft. Peres $(2011$, p. 5) even concludes that Brazil's industrial policies is marred with "losing policies". This means that the government has become a mere rescuer of ailing businesses, instead of creating new ones, or nurturing those with a competitive edge. This empirical observation supports the notion that businesses galvanized the government into action, rather than the other way around.

The current palpable discontent with economic growth tipping into recession and with reports over the festering corruption scandals, could, however, thrust the need for a thorough reform on the government's agenda. Electoral concerns could re-surface as a driving factor of thorough reform drive if the government wants to reboot Brazil's anemic economy. For the 1990s, Baker (2009, p. 264), Armijo $(2005,2013)$ and Armijo \& Faucher $(2010$, p. 71) found plausible and encouraging evidence that the initiatives and the continued commitment by the Brazilian policymakers for and to the Real-Plan, and its survival after Lula da Silva's electoral victory can been explained by the support of the broad masses for stable price levels and the constituents' dissatisfaction with the recurrent economic crises and cronyism.

These reforms could then be pushed through, even if they offend vested interests. But in the past decade, the government's policies have been tangled in a web of interests that are often dissenting, which further complicated the already onerous trade and tax regime, as the administration sought to placate each of these interests by distributing sweeteners in form of industry-specific tax exemptions. 


\section{REFERENCES}

Abu-El-Haj, Jawdat (2007) "From interdependence to neo-mercantilism: Brazilian capitalism in the age of globalization". Latin American Perspectives34 (5): 92-114.

Aggarwal, Vinod K., and Simon J. Evenett (2014) "Do WTO rules preclude industrial policy? Evidence from the global economic crisis". Business and Politcs, 16: 481-509.

Arbix, Glauco, and Scott B. Martin. (2010) "Beyond developmentalism and market fundamentalism in Brazil: Inclusionary state activism without statism.” Paper for the Workshop on States, Development, and Global Governance, Global Legal Studies Center and the Center for World Affairs and the Global Economy (WAGE), University of Wisconsin-Madison, March 12-13, 2010.

Armijo, Leslie Elliott (2005) “Mass democracy: The real reason that Brazil ended inflation?” World Development 33 (12): 2013-2027.

Armijo, Leslie Elliott, and Phillippe Faucher (2010) “"We have a Consensus”: Explaining political support for market reforms in Latin America.” In William C. Smith and Laura Gómez-Mera, eds., Market, state and society in contemporary Latin America. Chichester: Wiley-Blackwell: 51-82.

Baker, Andy (2009) The Market and the Masses in Latin America - Policy Reform and Consumption in liberalizing Economies. Cambridge: Cambridge University Press, 2009.

Ban, Cornel (2013) "Brazil's liberal neo-developmentalism: New paradigm or edited orthodoxy?" Review of International Political Economy, 20 (2): 298-331.

Bates, Robert H. (1999) Open-Economy Politics: The Political Economy of the World Coffee Trade. Princeton: Princeton University Press

Baumann, Renato (2002) “Trade policies, growth, and equity in Latin America.” In Evelyne Huber, ed., Model of Capitalism - Lessons for Latin America. Pennsylvania State University Press: 53-80.

Bergsman, Joel (1970) Brazil: Industrialization and Trade Policies. London: Oxford University Press.

Boschi, Renato Raul (2014). "Politics and trajectory in Brazilian capitalist development." In Uwe Becker, ed., The BRICs and Emerging Economies in Comparative Perspective. London: Routledge: 123-143.

Bresser-Pereira, Luiz Carlos (2011) "An account of new developmentalism and its structuralist macroeconomics." Brazilian Journal of Political Economy, 31 (3): 493-502.

Carrillo, Ian R. (2014) "The new developmentalism and the challenges to long-term stability in Brazil." Latin American Perspectives, 41 (5): 59-74.

CCM Information Science \& Technology (2013) Crop Protection South America - Monthly Report. CCM Newsletter, Guangzhou: Guangzhou CCM Information Science \& Technology Co., Ltd..

Costa, Carolina, and Ivete Simionatto (2012) "Como os dominantes dominam: o caso da bancada ruralista”. Temporalis, n. 24, p. 215-237.

Doctor, Marukh (2007) "Boosting investment and growth: the role of social pacts in the automotive industry". Oxford Development Studies, 35 (1): 105-130.

Filomeno, Felipe Amin (2014) Monsanto and Intellectual Property in South America. Basingstoke: Palgrave Macmillan.

Frieden, Jeffry A. (1991) Debt, Development and Democracy - Modern political economy and Latin America, 1965-1985. Princeton: Princeton University Press.

Gawande, Kishore, Bernard Hoekman, and Yue Cui (2011) "Determinants of trade policy responses to the 2008 financial crisis”. Washington, DC: The World Bank - International Trade Department.

Goldsmith, Peter D. (2008) “Soybean production and processing in Brazil”. Dans Soybeans: Chemistry, Production, Processing and Utilization, de Lawrence A. Johnson, Pamela J. White et Richard Galloway, 773-798. Champaign, Illinois: AOCS Press.

Gómez-Mera, Laura (2007) "Macroeconomic concerns and interstate bargains: Explaining illiberal policies in Brazil's automobile sector.” Latin American Politics and Society, 49 (1): 113-140.

Hopewell, Kristen (2014) "The transformation of state-business relations in an emerging economy The case of Brazilian agribusiness.” Critical Perspectives on International Business, 10(4), 291309: 291-309. 
ICCT. Brazil's Inovar-Auto incentive program. Policy Update, Washington: International Council on Clean Transportation (ICCT), 2013.

Katzenstein, Peter. Between Power and Plenty - Foreign Economic Policies of Advanced Industrial States. Madison, Wisconsin: The University of Wisconsin Press, 1978.

Kingstone, Peter R. (1999) Crafting Coalitions for Reform - Business Preferences, Political Institutions, and Neoliberal Reform in Brazil. Pennsylvania: Penn State University Press.

Kingstone, Peter R. (2009) “Sobering up and going global: Brazil's progress from populism and protectionism". Law \& Business Review of the Americas 15: 105-126.

Krugman, Paul R., and Maurice Obstfeld (2003) International Economics - Theory and Policy. Boston: Pearson Education.

Leibold, Kelvin, and Mauro Osaki (2009) “Soybean production: USA vs. Brazil”. Presentation Cash Crop Conference, Iowa State University.

Loureiro, Maria Rita (2009) "Economists in the Brazilian government: from developmentalist state to neoliberal policies.” In Verónica Montecinos and John Markoff, eds., Economists in the Americas. Cheltenham: Edward Elgar Publishing: 100-141.

Love, Joseph L. (2005) “The rise and fall of structuralism.” In Valpy FitzGerald and Rosemary Thorp, eds., Economic Doctrines in Latin America - Origins, Embedding and Evolution. Basingstoke: Palgrave MacMillan: 157-181.

Machado, Marcela (2013) Doação ou investimento?: a atuação legislativa dos parlamentares da bancada ruralista e a questão do financiamento de campanha. Dissertation, Brasília: Universidade de Brasília.

Montero, Alfred (2004) “Competitive federalism and distributive conflict in democratic Brazil." In Mauricio A. Font, Anthony Peter Spanakos and Cristina Bordin, eds., Reforming Brazil. Maryland: Lexington Books: 137-160.

Morais, Lecio, and Alfredo Saad-Filho (2012) "Neo-developmentalism and the challenges of economic policy-making under Dilma Rousseff.” Critical Sociology 38 (6): 789-798.

Moravcsik, Andrew (1997) "Taking preferences seriously: a liberal theory of international politics." International Organization 51 (4): 513-553.

Musacchio, Aldo, and Sergio G. Lazzarini (2014) Reinventing State Capitalism - Leviathan in Business, Brazil and Beyond. Cambridge, Massachusetts: Harvard University Press.

Navarro, Rodrigo, Murillo Dias, and André Valle (2013) "BMW and Brazilian federal government enhancing the autonomotive industry regulatory environment" International Journal of Arts and Science, 6 (2): 551-567.

OECD (2013) "Increasing the pie: Productivity and competitiveness of Brazilian firms". OECD Economic Surveys: Brazil 2013, OECD Publishing.

Oh, Seung-Youn (2014) "Shifting gears: industrial policy and automotive industry after the 2008 financial crisis.” Business and Politics, 16 (4): 641-665.

Peres, Wilson (2011) "Industrial policies in Latin America". Working Paper UN Economic Commission for Latin America and the Caribbean (ECLAC), 2011.

Posthuma, Anne Caroline (2005) "Industrial renewal and inter-firm relations in the supply-chain of the Brazilian automotive industry. SEED Working Paper, Geneva: International Labour Organization (ILO).

Richardson, Neal Philip (2012) The Politics of Abundance: Export Agriculture and Redistributive Conflict in South America. Dissertation, Berkeley : UC Berkeley Electronic Theses and Dissertations.

Rivoli, Pietra (2009) The Travels of a T-Shirt in the Global Economy. Hoboken, New Jersey: John Wiley \& Sons, Inc.

Schirm, Stefan A. "Domestic Politics.Theorien und Societal Approach.” In Joscha Wullweber, Antonia Graf and Maria Behrens, eds., Theorien der Internationalen Politischen Ökonomie. Wiesbaden: Springer: $167-183$.

Schirm, Stefan A. "Global politics are domestic politics: a societal approach to divergence in the G20." Review of international Studies, 39 (3): 685-706. 
Schirm, Stefan A. (2009) "Ideas and interests in global financial governance: comparing German and US preference formation." Cambridge Review of International Affairs 22 (3): 501-521.

Schnepf, Randall D., Erik Dohlman, and Christine Bolling (2001) Agriculture in Brazil and Argentina: Developments and Prospects for Major Field Crops. WRS-01-3, Washington, D.C.: U.S. Department of Agriculture, Agriculture and Trade.

Shapiro, Helen (1994) Engines of Growth - The State and Transnational Auto Companies in Brazil. Cambridge: Cambridge University Press.

Sikkink, Kathryn (1991) Ideas and Institutions - Developmentalism in Brazil and Argentina. Ithaca: Cornell University Press.

Sindipeças (2011) A indústria de autopeças: pressões de todos os lados. Presentation, São Paulo: Sindipeças.

US cable. Brazil: Minister of Agriculture resigns after tussle over farm debt relief. Report, Brasilia: U.S. Embassy, 2006.

Whitehead, Laurence (2005) "The shifting foundations of economic liberalism in Latin American public policy.” In Valpy FitzGerald and Rosemary Thorp, eds. Economic Doctrines in Latin America, Basingstoke: Palgrave Macmillan: 245-264.

Williamson, John (1990) "What Washington means by policy reform". Speeches and Papers, Washington, DC: Peterson Institute for International Economics.

World Bank (2014) Global Economic Prospects: Shifting Priorities, Building for the Future. Washington, D.C.: World Bank. 